\title{
Use of dominance analysis in selecting the best cropping technique based on long term agronomic experiments
}

\author{
Giuliano Vitali, Loretta Triberti, Guido Baldoni \\ Department of Agricultural Sciences, University of Bologna, Italy
}

\begin{abstract}
Yield averages and variability from three long-term agronomic experiments (LTAEs) have been used in a preference scheme for cropping system options by means of a dominance approach. Preference maps are obtained and include both parametric and stochastic dominance based on yield level and risk for wheat and maize crops grown in the Mediterranean area. Dominance method could add to classic ANOVA the direction of the effect of a treatment and a comparative approach. It allowed comparing technical options and practices on the basis of treatments explored in 3 still running LTAEs: rotation, tillage, mineral fertilisation level and organic amendment.
\end{abstract}

\section{Introduction}

In the last decades, agricultural risks have been mainly related to environmental hazards that are linked to the use of fertilisers and pesticides. In this instance, risk has been expressed as the amount of polluted soils and ground-water concentration levels. Agricultural activity also induces risk in terms of hydrological

Correspondence: Giuliano Vitali, Department of Agricultural Science, University of Bologna, via Fanin 44, 40127 Bologna, Italy.

E-mail: giuliano.vitali@unibo.it

Key words: Dominance; Long-term experiment; Rotations; Tillage; Fertilisation.

Acknowledgments: the paper has been developed in the framework of project PRIN IC-FAR funded by Italian Ministry of Agricultural, Food and Forestry Policy. We are also grateful to M. Canavari for helpful suggestions on risk theory applications.

See online Appendix for additional materials.

Conference presentation: SIA XLIV Congress, Bologna, 2015.

Received for publication: 3 February 2016.

Revision received: 3 October 2016.

Accepted for publication: 3 October 2016.

CCopyright G. Vitali et al., 2017

Licensee PAGEPress, Italy

Italian Journal of Agronomy 2017; 12:765

doi:10.4081/ija.2017.765

This article is distributed under the terms of the Creative Commons Attribution Noncommercial License (by-nc 4.0) which permits any noncommercial use, distribution, and reproduction in any medium, provided the original author(s) and source are credited. land instability (landslides), soil conservation (erosion), and air pollution (e.g. spreading of slurries near urban areas). All of these risks deal with environmental and human health. But risk is an important issue also from an economic standpoint: farm income depends on crop yields, which can be highly variable over the years, mainly influenced by market, weather (Uzea et al., 2014), and cultural practices.

A cropped land is an ecosystem that farmer maintains in a plagioclimax, controlling the effects of weather uncertainties and the other species competition. Recently climate is changing the rules of the game, adding fluctuations that farmers are not ready to cope with: longer drought spells, rainfalls of huge intensity and duration, temperature fluctuations are some relevant features of the changing climate. Mavi and Tupper (2004) identified in weed germination and survival of insect and pests the main processes that severe weather brings about on crop yields. Mugo (1999) claimed that intensification of extreme events will increase seedling sufferance to frost and water stress.

Several options have been studied to reduce risk, including the choice of a proper variety and timing of cultural operations (e.g. sowing, fertilising, tillage; Sivakumar and Iotha, 2008). Farmers know that a full prevention is hardly attainable: an adverse event happening at a critical phenological stage can be sufficient to cancel out a year's yield.

Net incomes from arable crop productions are decreasing and a common way to address risk is the adoption of insurance: a way to get around the problem that allows continuing following traditional cultural protocols. Nevertheless, farmers are eager to know which cropping system can better ensure the economic sustainability in a context of high weather fluctuation.

To this scope, long-term data are required, and long-term agronomic experiments (LTAEs) can offer an unexploited resource of knowledge.

Nowadays many LTAEs are available all over the world. The first ones were established in middle $19^{\text {th }}$ century and were aimed at understanding the effects on crop growth and yield of new industrial products (Acock and Acock, 1991; Johnston and Powlson, 1994).

In Italy the first LTAEs started in the Sixties, and three of them (Prova64, Prova29 and Prova 31 ) are still running in Bologna. All these trials focus on yield and soil fertility under various crop rotations, tillage and fertilisation/amendment. They allow the collection of information on the behaviour of crops in the Mediterranean agro-ecosystem, where practices like the return of crop residues to soil already showed positive effects on yield (Kamkar et al., 2014).

Most of yield data are affected by a high variability, which classical statistical analysis interprets as error, useful to test significance of treatments. Variability comes from several issues when dealing with a complex experimental design (Payne, 2015). Some of it can be ascribed to genotype $\mathrm{x}$ environment and used to evaluate stability and reliability of a cultivation (Annicchiarico, 2002). Some variability is related to occurrence of events, whose proba- 
bility is bound to a complex causality chain that affects risk perception: insurance operators identify risk as the probability of a claim due to the occurrence of an unfavourable event determining a significant yield reduction (Castaneda-Vera et al., 2015).

In the present paper, yield variability from LTAEs is used to estimate productivity risk in crop investment (Mapp and Helmers, 1984; Harwood et al., 1999) and how it is influenced by agronomic practices (Williams et al., 1990; Laanemets et al., 2011). The study uses a model widely employed in decision process, the dominance one, oriented to compare/select alternative practices, to verify the possibility to synthesise the large amount of information available from LTAEs to increase their accessibility for decision purposes.

\section{Materials and methods}

In Bologna's LTAEs [see on-line resources for details: http://www.icfar.it/BO1.html (Prova29); http://www.icfar.it/ BO2.html (Prova64); http://www.icfar.it/BO3.html (Prova31); http://www.scienzeagrarie.unibo.it/it/servizi-e-strutture/esperienze-agronomiche-a-lungo-termine-ealt], yield data have been collected for different combinations of fertilisation, rotation and tillage, as shown in Table 1.

Prova64 and Prova 29 are set in Cadriano (Italy, prov. Bologna, Lat 4433'08', Lon $11^{\circ} 24^{\prime} 42^{\prime \prime}, 30 \mathrm{~m}$ asl) while Prova 1 is located

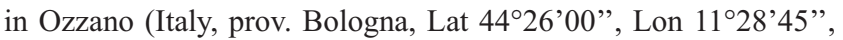
$100 \mathrm{~m}$ asl). The sites have the same climate (sub-continental temperate, Koppen) with $700 \mathrm{~mm}$ annual precipitation, and similar alluvial soils (silty loam, udic ustochrepts fine silty, mixed mesic, soil taxonomy). In Cadriano a shallow water-table is present, not in Ozzano (Figure 1).

Prova64, detailed in Triberti et al. (2016), started in the autumn 1966 and aimed at studying the combined effects of mineral fertilisers on maize and wheat yield, grown in various rotations. Continuous crops are as follows: Wcont, continuous winter wheat (Triticum aestivum L.); Ccont, continuous maize (Zea mays L.); 2-year rotation (Rot2): maize - wheat; 9-year rotation (Rot9): $3 \times$ [maize-wheat] $-3 \times$ alfalfa (Medicago sativa $\mathrm{L}$.).

Within each rotation, two levels of mineral fertilisers, including control are adopted, as shown in Table 2, combined with treatment with or without farmyard manure with an annual average supply of $20 \mathrm{Mg} \mathrm{ha}^{-1}$ year $^{-1}$ of fresh material. Manure distribution takes place early in the autumn and it is readily ploughed under to $0.40 \mathrm{~m}$ depth. It is supplied before maize in the Rot2, once every two years in the continuous cereals (double dose) and before alfalfa in the Rot9 (triple dose). The treatments are repeated in two blocks with the presence, each year, of both maize and wheat of the biennial rotation.

Prova29 started 2 years later than Prova64 to assess the response of crops to 4 organic amendment treatments: control (Ctrl), cattle manure (FYM), cattle slurry (Slur), crop residues (Res). They are combined with 4 rates of nitrogen (N) (as urea): control (N0), $100 \mathrm{~kg}$ $\mathrm{N} / \mathrm{ha}(\mathrm{N} 100), 200 \mathrm{~kg} \mathrm{~N} / \mathrm{ha}(\mathrm{N} 200), 300 \mathrm{~kg} \mathrm{~N} / \mathrm{ha}(\mathrm{N} 300)$. The trial is based on a 2 -year crop rotation maize (Zea mays L.)-winter wheat

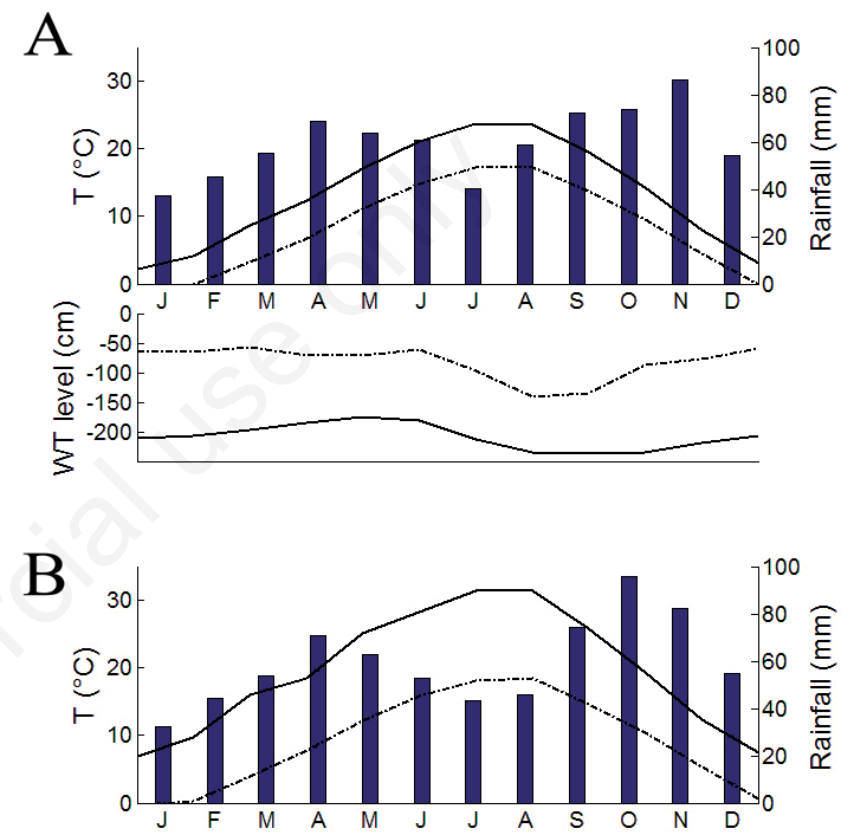

Figure 1. Climate in Cadriano (A) and Ozzano (B) includes monthly average precipitation (bars), maximum and minimum temperature (respectively continuous and dashed lines). Water table is only present for Cadriano.

Table 1. Treatments investigated in Bologna long-term agronomic experiments.

\begin{tabular}{ccccccc} 
LTAE & Year of set-up & Years analysed & Tillage & \multicolumn{2}{c}{$\begin{array}{c}\text { Treatments } \\
\text { Rotation }\end{array}$} \\
& & & Mineral fertilisation & Organic amendments \\
Prova64 & 1966 & $1985-2011$ & $X$ & $\checkmark$ & $\checkmark$ & $\checkmark$ \\
Prova29 & 1968 & $1981-2003$ & $X$ & $X$ & $\checkmark$ & X \\
\hline Prova31 & 1985 & $1988-2003$ & $\checkmark$ & $\checkmark$ & $X$ \\
\hline
\end{tabular}

LTAE, long-term agronomic experiments.

Table 2. Mineral fertilisers rates in Prova64.

\begin{tabular}{|c|c|c|c|c|}
\hline \multirow{2}{*}{ Crop } & \multicolumn{2}{|c|}{ NP1 } & \multicolumn{2}{|c|}{ NP2 } \\
\hline & $\mathrm{N}\left[\mathrm{kg} \mathrm{ha}^{-1}\right]$ & $\mathrm{P}_{2} \mathrm{O}_{5}\left[\mathrm{~kg} \mathrm{ha}^{-1}\right]$ & $\mathrm{N}\left[\mathrm{kg} \mathrm{ha}^{-1}\right]$ & $\mathrm{P}_{2} \mathrm{O}_{5}\left[\mathrm{~kg} \mathrm{ha}^{-1}\right.$ \\
\hline Wheat & 100 & 50 & 200 & 100 \\
\hline Maize & 150 & 50 & 300 & 100 \\
\hline Alfalfa & 0 & 150 & 0 & 300 \\
\hline
\end{tabular}


(Triticum aestivum L.), with maize cropped in odd years and wheat in even ones. Crop residues have been always removed at harvest and, as the other organic amendments (see composition in Table 3), they were applied in August after wheat harvest and in September after maize harvest at the rate of $6.0 \mathrm{Mg}$-dry matter (DM)/ha and 7.5 $\mathrm{Mg}-\mathrm{DM} / \mathrm{ha}$ respectively. All amendments are immediately buried under by mouldboard ploughing to $40 \mathrm{~cm}$ depth. Further details are reported in Triberti et al. (2008).

Prova 31 started in 1985 and aimed at investigating the effects on wheat (Triticum durum spp. durum Desf.) of several combinations of tillage (various depths and soil mixing) with several crop precessions. Wheat has been grown in continuous cropping or in biennial rotation with winter and summer crops (Table 4), and within a 4-year rotation (Rot4): sugarbeet-wheat-sunflower-barley.

In Prova 31 three tillage successions were compared. In two of them a conventional mouldboard ploughing to two depths was performed, whereas in the third succession shallow ploughing was substituted with chiselling and surface rotary harrowing, as listed in Table 5. Further details can be found in Toderi et al. (2000).

All LTAEs described so far adopt a mixed model scheme (split-plot), with two, four and three replicates for Prova64, Prova29 and Prova31, respectively, based on plots of 56, 24 and $33 \mathrm{~m}^{2}$ of area, respectively.

Other agronomic practices reflect what is locally common. Winter crop is sown in mid October, while summer crops at the beginning of April. The formers are harvested at the end of June, summer crops from the end of August to mid September. Alfalfa is sown in mid February and mown three-four times per year, from the first week of May to the end of September. With the exception of Prova 31 and in the alfalfa ley, soil is mouldboard ploughed to $0.40 \mathrm{~m}$ depth in the autumn of each year.

Mineral $\mathrm{N}$ is applied in two fractions: in wheat $30 \%$ of the rate at the end of tillering and $70 \%$ at the beginning of stem elongation; in maize $50 \%$ at seeding and $50 \%$ at the $4^{\text {th }}$ leaf stage. A conventional chemical control of weeds and diseases is performed. Crops are not irrigated.

Bologna LTAEs changed slightly over the years in terms of crop cultivars, mechanical tools, and commercial fertilisers. However, all modifications have been performed preserving the initial design, in agreement with Poulton (1996).

Observed yields have been fully analysed in relation to treatments by classical ANOVA (Toderi et al., 2000; Triberti et al.,

Table 3. Mean composition of amendments used in Prova29.

\begin{tabular}{lccc} 
Organic amendments & Organic C (\% DM) & N(\% DM) & C:N \\
FYM & 33.1 & 2.68 & 12.3 \\
Slur & 39.0 & 2.81 & 13.9 \\
\hline Res1 & 32.8 & 0.47 & 69.8 \\
Res2 & 32.6 & 0.70 & 46.6 \\
\hline
\end{tabular}

C, carbon; N, nitrogen; DM, dry matter; FYM, cattle manure; Slur, cattle slurry; Res1, wheat straw; Res2, maize stalks.

Table 4. Winter and summer crops tested in Prova31.

\begin{tabular}{|c|c|}
\hline Winter crops & Summer crops \\
\hline $\begin{array}{l}\text { Wheat (Triticum durum } \\
\text { spp. Durum Husn.) }\end{array}$ & Maize (Zea mays L.) \\
\hline Barley (Hordeum vulgare L.) & Sorghum (Sorghum bicolor (L.) Moench) \\
\hline Oat (Avena sativa L.) & Sugarbeet (Beta vulgaris L.) \\
\hline $\begin{array}{l}\text { Triticale (Triticum x Secale } \\
\text { Wittmack) }\end{array}$ & Sunflower (Helianthus annuus L.) \\
\hline
\end{tabular}

Table 5. Tillages used in Prova31.

\begin{tabular}{lcccc} 
& \multicolumn{2}{c}{ Winter crop rotation } & \multicolumn{2}{c}{ Summer crop rotation } \\
& Preceding crop & Wheat & Preceding crop & Wheat \\
Deep ploughing & $50 \mathrm{~cm}$ & $25 \mathrm{~cm}$ & $50 \mathrm{~cm}$ & $25 \mathrm{~cm}$ \\
Shallow ploughing & $25 \mathrm{~cm}$ & $25 \mathrm{~cm}$ & $25 \mathrm{~cm}$ & $25 \mathrm{~cm}$ \\
\hline Reduced mixing & $\mathrm{CH}+\mathrm{RH}$ & $\mathrm{RH}$ & $25 \mathrm{~cm}$ & $\mathrm{RH}$ \\
\hline
\end{tabular}

$\mathrm{CH}$, chisel ploughing; RH, rotary harrow.

Table 6. Synthesis of considered treatments in long-term agronomic experiments.

\begin{tabular}{|c|c|c|c|c|c|c|c|}
\hline & Rotation & Amendment & $\begin{array}{c}\text { Mineral } \\
\text { fertilisation }\end{array}$ & $\begin{array}{l}\text { Tillages with } \\
\text { winter crop }\end{array}$ & $\begin{array}{l}\text { Tillages with } \\
\text { summer crop }\end{array}$ & Winter crops & Summer crops \\
\hline $\begin{array}{l}\text { Prova64 } \\
\text { (wheat and } \\
\text { maize yield) }\end{array}$ & $\begin{array}{l}\text { Cont, } \\
\text { Rot2, } \\
\text { Rot } 9\end{array}$ & $\begin{array}{l}(\mathrm{Ctrl}) \\
\text { M-FYM }\end{array}$ & $\begin{array}{c}\text { (Ctrl) } \\
\text { NP1, NP2 }\end{array}$ & - & - & - & - \\
\hline $\begin{array}{l}\text { Prova29 } \\
\text { (wheat and maize yield) }\end{array}$ & - & $\begin{array}{l}\text { Ctrl, } \\
\text { FYM, } \\
\text { Res, } \\
\text { Slur }\end{array}$ & $\begin{array}{l}\text { N0, } \\
\text { N100, } \\
\text { N200, } \\
\text { N300 }\end{array}$ & - & - & - & - \\
\hline $\begin{array}{l}\text { Prova31 } \\
\text { (wheat yield) }\end{array}$ & - & - & - & $\begin{array}{l}\text { DT-RH, } \\
25-25, \\
50-25\end{array}$ & $\begin{array}{l}25-\mathrm{RH} \\
25-25 \\
50-25\end{array}$ & $\begin{array}{c}\text { Barley, } \\
\text { oat, } \\
\text { triticale, } \\
\text { wheat, } \\
\text { legumes }\end{array}$ & $\begin{array}{l}\text { Maize, } \\
\text { sorghum, } \\
\text { soybean, } \\
\text { sugarbeet, } \\
\text { sunflower }\end{array}$ \\
\hline
\end{tabular}

Cont, continuous; Rot2, 2-year rotation; Rot 9, 9-year rotation; Ctrl, control; FYM, cattle manure; NP1, mineral level 1; NP2, mineral level 2; Res, residual crop; Slur, cattle slurry; N0, rate 0 of nitrogen, i.e. control; N100, 100 kg N/ha; N200, 200 kg N/ha; N300, 300 kg N/ha; DT-RH, non-mixing tillage; 25-25, repeated tillage; 50-25, alternate deep tillage; 25-RH, reduced tillage; rot4, 4-year rotation. 
2008, 2016). In this analysis, instead, yield variability is interpreted in term of risk within the investment decision framework, by means of the dominance model. Given two distributions of yields $(F, G)$ dominance is a criterion used to define a comparative preference (e.g. to say that $F$ is better than $G$ ). The classical approach is a parametric one: it uses the average yields and some dispersion index to obtain a measure of risk. In this case dominance is the answer to the statement: $F$ is better than $G$ if average $(F) \geq$ average $(G)$ and $\operatorname{risk}(F) \leq \operatorname{risk}(G)$. As a measures of risk they have been proposed unilateral metrics (below-mean variance) or based on target (below-target variance): the latter is used to identify the failure of a choice when return is below an expected yield (the target).

Recently the stochastic dominance approach has become popular (Levy, 2015), and in particular, the second-degree stochastic dominance (SSD), because of its proved equivalence to the meantarget semivariance model (Fishburn, 1977). SSD states that F SSD
$G$ (read $F$ is better than $G$ according to the $S S D$ criterion) if $F \neq G$ and $\int \mathrm{G}(\mathrm{y}) \mathrm{dy} \leq \int \mathrm{F}(\mathrm{y})$ dy where $y$ is the yield: in practice the cumulated distributions (Appendix Figures 1-3) are compared directly and a dominance occurs only if curves do not intersect.

\section{Results and discussion}

Present study takes into consideration only part of outputs of 3 LTAEs, which complexity and variability is far larger than that synthesised here (Toderi et al., 2000; Triberti et al., 2008, 2016). For Prova64 and Prova29 evaluations refer to wheat and maize yields, whereas for Prova31 only wheat yields are analysed. Treatments investigated are summarised in Table 6.

Mean value and standard deviation of yields are given in

Table 7. Dominance map for Prova64.

\begin{tabular}{|c|c|c|c|c|c|c|c|c|c|c|c|c|c|c|c|c|c|c|c|}
\hline $\begin{array}{l}\mathrm{Tr} \text { _1 } \\
\mathrm{Tr} \text { _2 }\end{array}$ & & Ctrl & M & NP1 & $\begin{array}{l}\text { Cont } \\
\text { NP1-M }\end{array}$ & NP2 & NP2-M & Ctrl & M & NP1 & $\begin{array}{r}\text { Rot2 } \\
\text { NP1-M }\end{array}$ & NP2 & NP2-M & Ctrl & M & NP1 & $\begin{array}{c}\text { Rot9 } \\
\text { NP1-M }\end{array}$ & NP2 & NP2-M \\
\hline Prov & & & & & & & & & & & & & & & & & & & \\
\hline Cont & $\begin{array}{l}\text { Ctrl } \\
\text { M } \\
\text { NP1 } \\
\text { NP1-M } \\
\text { NP2 } \\
\text { NP2-M }\end{array}$ & & & $\begin{array}{l}S \\
P\end{array}$ & $\begin{array}{l}S \\
P \\
P\end{array}$ & $\begin{array}{c}\text { S } \\
\text { PS } \\
\text { PS }\end{array}$ & $\begin{array}{c}\text { S } \\
\text { PS } \\
\text { S } \\
\text { S }\end{array}$ & $\mathrm{P}$ & $\mathrm{S}$ & $\begin{array}{c}\text { S } \\
\text { PS } \\
P\end{array}$ & $\begin{array}{c}\text { S } \\
\text { PS } \\
\text { S }\end{array}$ & $\begin{array}{c}\text { S } \\
\text { PS } \\
\text { S } \\
\text { S } \\
\\
P\end{array}$ & $\begin{array}{c}\text { S } \\
\text { PS } \\
\text { S }\end{array}$ & & $\begin{array}{l}\mathrm{S} \\
\mathrm{P}\end{array}$ & $\begin{array}{c}\text { S } \\
\text { PS }\end{array}$ & $\begin{array}{c}\text { S } \\
\text { PS } \\
\text { S }\end{array}$ & $\begin{array}{c}\text { S } \\
\text { PS } \\
\text { S } \\
\text { S }\end{array}$ & $\begin{array}{c}\text { S } \\
\text { PS } \\
\text { S } \\
\text { S }\end{array}$ \\
\hline Rot2 & $\begin{array}{l}\text { Ctrl } \\
\text { M } \\
\text { NP1 } \\
\text { NP1-M } \\
\text { NP2 } \\
\text { NP2-M }\end{array}$ & & & $\begin{array}{l}P \\
P\end{array}$ & $\begin{array}{l}P \\
P\end{array}$ & $\begin{array}{l}P \\
P\end{array}$ & $\begin{array}{l}P \\
P\end{array}$ & & & $\begin{array}{l}P \\
P\end{array}$ & $\begin{array}{l}\mathrm{P} \\
\mathrm{P}\end{array}$ & $\begin{array}{l}P \\
P \\
P \\
P\end{array}$ & $\begin{array}{l}\mathrm{P} \\
\mathrm{P}\end{array}$ & & $\mathrm{P}$ & $\begin{array}{l}P \\
P\end{array}$ & $\begin{array}{l}P \\
P\end{array}$ & $\begin{array}{l}P \\
P\end{array}$ & $\begin{array}{l}\mathrm{P} \\
\mathrm{P}\end{array}$ \\
\hline Rot 9 & $\begin{array}{l}\text { Ctrl } \\
\text { M } \\
\text { NP1 } \\
\text { NP1-M } \\
\text { NP2 } \\
\text { NP2-M }\end{array}$ & & & $\begin{array}{l}P \\
P \\
P\end{array}$ & $\begin{array}{l}P \\
P \\
P \\
P \\
P\end{array}$ & $\begin{array}{l}P \\
P \\
P \\
P \\
P\end{array}$ & $\begin{array}{l}S \\
S\end{array}$ & & S & $\begin{array}{c}S \\
P S \\
P \\
P \\
P \\
P\end{array}$ & $\begin{array}{c}\text { S } \\
\text { PS } \\
\text { S }\end{array}$ & $\begin{array}{c}\text { S } \\
\text { PS } \\
\text { S } \\
\text { S } \\
P \\
P\end{array}$ & S & & & $\mathrm{P}$ & $\begin{array}{l}\mathrm{P} \\
\mathrm{P} \\
\mathrm{P}\end{array}$ & $\begin{array}{c}\text { S } \\
\text { PS } \\
\text { S }\end{array}$ & $\begin{array}{c}S \\
P S \\
S \\
P\end{array}$ \\
\hline Prove & & & & & & & & & & & & & & & & & & & \\
\hline Cont & $\begin{array}{l}\text { Ctrl } \\
\text { M } \\
\text { NP1 } \\
\text { NP1-M } \\
\text { NP2 } \\
\text { NP2-M }\end{array}$ & & S & P & $\begin{array}{l}P \\
P\end{array}$ & $\begin{array}{c}\text { S } \\
\text { PS } \\
P S \\
P\end{array}$ & $\begin{array}{c}\text { S } \\
\text { PS } \\
P S \\
P S \\
P\end{array}$ & & $\begin{array}{l}\mathrm{PS} \\
\mathrm{P} \\
\mathrm{P} \\
\mathrm{P} \\
\mathrm{P} \\
\mathrm{P}\end{array}$ & $\begin{array}{c}\text { PS } \\
\text { PS } \\
P \\
P \\
P \\
P\end{array}$ & $\begin{array}{c}\text { S } \\
\text { PS } \\
\text { PS }\end{array}$ & $\begin{array}{c}\text { S } \\
\text { PS } \\
\text { PS } \\
\text { PS } \\
\text { P } \\
P\end{array}$ & $\begin{array}{l}\mathrm{S} \\
\mathrm{P} \\
\mathrm{P}\end{array}$ & $\begin{array}{l}P \\
P\end{array}$ & $\begin{array}{l}S \\
P \\
P\end{array}$ & $\begin{array}{c}\text { S } \\
\text { PS } \\
P\end{array}$ & $\begin{array}{c}\text { S } \\
\text { PS } \\
\text { S }\end{array}$ & $\begin{array}{c}\text { S } \\
\text { PS } \\
\text { PS } \\
\text { PS }\end{array}$ & $\begin{array}{c}\text { S } \\
\text { PS } \\
\text { S } \\
\text { S } \\
\text { S }\end{array}$ \\
\hline Rot2 & $\begin{array}{l}\text { Ctrl } \\
\text { M } \\
\text { NP1 } \\
\text { NP1-M } \\
\text { NP2 } \\
\text { NP2-M }\end{array}$ & & & & & & P & & $\begin{array}{l}\mathrm{P} \\
\mathrm{P}\end{array}$ & $\mathrm{P}$ & $\mathrm{P}$ & $\mathrm{P}$ & & & & $\begin{array}{l}\mathrm{S} \\
\mathrm{S}\end{array}$ & & $\begin{array}{l}S \\
S\end{array}$ & $\begin{array}{l}\text { S } \\
\text { S } \\
\text { S } \\
\text { S } \\
\text { S }\end{array}$ \\
\hline Rot9 & $\begin{array}{l}\text { Ctrl } \\
\text { M } \\
\text { NP1 } \\
\text { NP1-M } \\
\text { NP2 } \\
\text { NP2-M }\end{array}$ & & & & & PS & PS & & PS & $\mathrm{P}$ & $\begin{array}{l}\mathrm{S} \\
\mathrm{P} \\
\mathrm{P} \\
\mathrm{P} \\
\\
\mathrm{P}\end{array}$ & $\begin{array}{c}P S \\
P \\
P \\
\\
P\end{array}$ & $\begin{array}{l}\mathrm{P} \\
\mathrm{P} \\
\mathrm{P}\end{array}$ & & $\mathrm{S}$ & S & $\mathrm{S}$ & $\begin{array}{l}\mathrm{S} \\
\mathrm{P} \\
\mathrm{P} \\
\\
\mathrm{P}\end{array}$ & $\begin{array}{l}\mathrm{S} \\
\mathrm{S} \\
\mathrm{S} \\
\mathrm{S}\end{array}$ \\
\hline
\end{tabular}

Tr_1, treatment 1; Tr_2, treatment 2; Cont, continuous; Rot2, 2-year rotation; Rot9, 9-year rotation; Ctrl, control; M, manure; NP1, mineral level-1; NP1-M, mineral level-1 plus manure; NP2, mineral level-2; NP2-M, mineral level-2 plus manure; P, parametric dominance; S, stochastic dominance. 
Appendix Table 1. Plots of cumulated distributions of experimental yields of Bologna LTAEs used to test stochastic dominance are given in Appendix Figures 1-3, for the three LTAEs, respectively.

Tables 7, 8 and 9 show both parametric (P) and stochastic (S) dominance of treatments reported on column heading in mutual comparison to those reported in row heading.

Because of natural ordering of fertilisation treatment levels, triangular structures are quite common in Tables 7 (Prova64) and 8 (Prova29). On the contrary, a natural ordering cannot be assumed for amendment (Table 8, Prova29), tillage and preceding crop (Table 9, Prova31).

In Prova64 (Table 7) the importance of mineral fertilisation and rotations are both relevant on wheat and maize yields, but in between the map some dominances are worthwhile to be discussed.

On wheat there is a lack of efficacy of the higher mineral level (NP2) when comparing treatments within a same rotation. On the other hand, manure (treatment $\mathrm{M}$ ) is effective at the low level of mineral fertiliser, but it becomes ineffective when combined at high mineral rate.
Rotation 2 seems better than continuous crops using stochastic dominance: results change adopting the parametric model: the same occurs when comparing Rot9 to continuous wheat.

Quite the same trend occurs when comparing Rot2 to Rot9 [3(maize-wheat) - 3(alfalfa)].

On maize as well yield manure shows a lack of efficacy, especially when comparing Rot 2 to continuous crop. Within Rot2, there is also a lack of dominance of the mineral supply. Rot2 and Rot9 are in general preferable to continuous wheat and, again, Rot2 to Rot9. Thus in wheat the three years of alfalfa do not seem to give dominance.

In Prova29 (Table 8) the stochastic dominance is less frequent. In general, there is a marked difference between the behaviour of FYM with respect to Res and Slur amendments, though that depends on the mineral levels.

The combination of amendments with the higher mineral level (N300) seems to affect negatively both wheat and maize yield values.

About wheat yields, with the levels N100 and N200, FYM is preferable than Res/Slur but that does not happen at the highest

Table 8. Dominance map for Prova29.

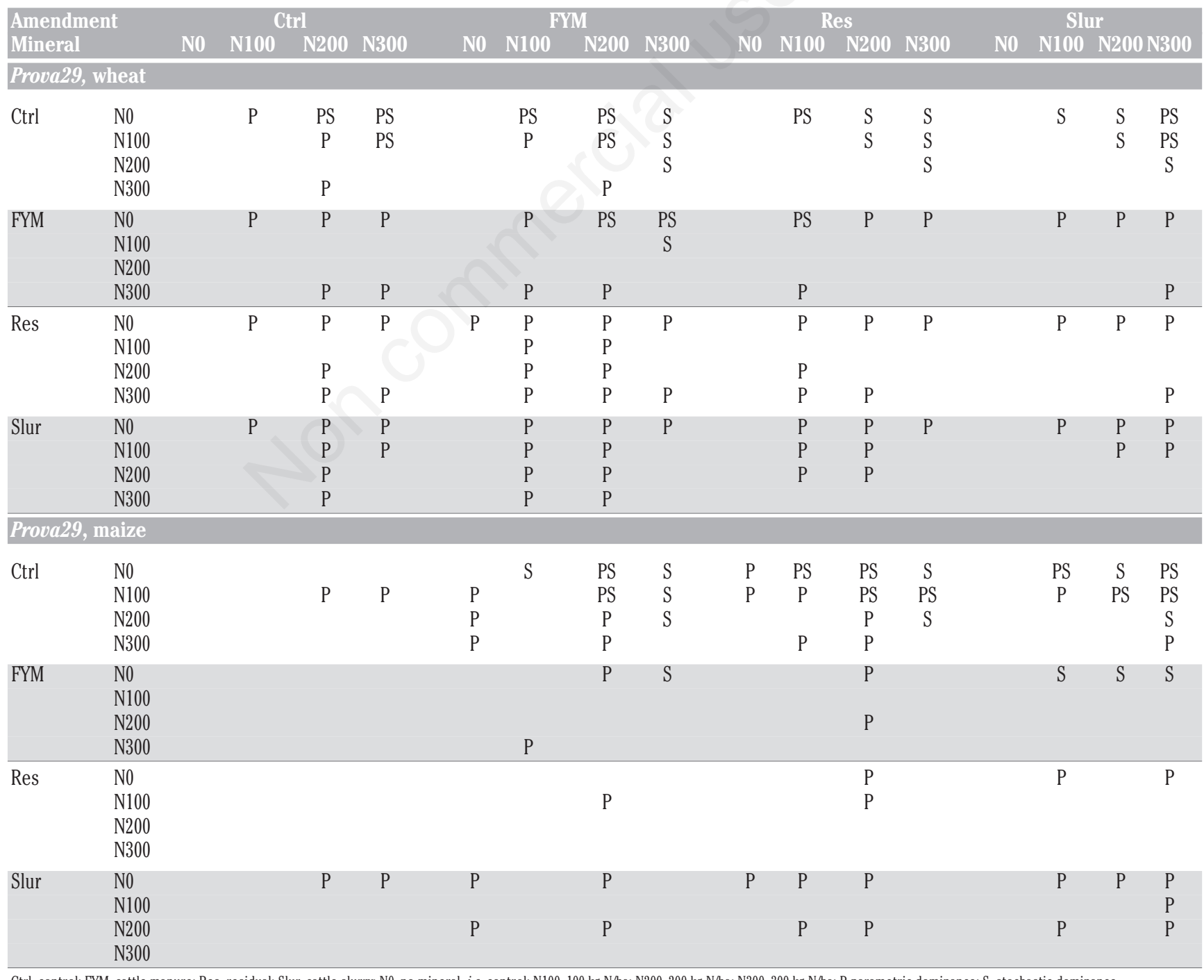

Ctrl, control; FYM, cattle manure; Res, residual; Slur, cattle slurry; N0, no mineral, i.e. control; N100, $100 \mathrm{~kg} \mathrm{N/ha;} \mathrm{N200,} 200 \mathrm{~kg} \mathrm{N/ha;} \mathrm{N300,} 300 \mathrm{~kg}$ N/ha; P, parametric dominance; S, stochastic dominance. 
mineral rate (N300), in which case negative effects could be due to an excessive dose. At the highest rate, lack of Res and Slur addition is preferable (see column Ctrl - N200-N300).

Regarding maize, yields amendments FYM, Res and Slur always dominates on control, even though not systematically.

In Prova31 (Table 9), the lack of an implicit natural ordering in treatments makes dominance distribution more scattered. In general, there is a strong dependence of wheat yield on preceding crop and on some tillage types.

In the case of winter crops, legumes and oat are markedly preferable than other precessions, quite independently on tillage.

Among the others effects emerges the oat precession dominance with the 50-25 tillage, and triticale with tillage types 25-25 and 50-25. In the case of a reduced tillage the continuous wheat dominates.

Regarding the summer preceding crops, there is a marked dominance of soybean with the 25-25 tillage and of Rot4 in rela- tion to which there are more cases of dominance for 25-RH tillage.

Among other effects, it can be noticed the dominance within sugarbeet plots, of the reduced tillage, and the dominance of sugarbeet on sunflower with 25-25 tillage.

All of the observation agree with previous papers (Toderi et al., 2000; Triberti et al., 2008, 2016) and can be mainly explained in terms of the effect of soil mixing on weeds and pathogens, and the effect of crop residues on $\mathrm{N}$ immobilisation.

In particular dominance maps confirm that the combination of crop sequence with an optimal fertiliser scheme can improve yield in agreement with Borghi et al. (1995).

The supply of mineral $\mathrm{N}$ and organic amendments implies complex dynamics related to mineralisation processes, which may affect $\mathrm{NO}_{3}{ }^{-}$availability (Nannipieri, 1993). Such complexity is certainly influenced by soil condition, which is driven by the interactions of weather and tillage, and could determine a great variability of yields, that is interpreted here in terms of risk.

Table 9. Dominance map for Prova31.

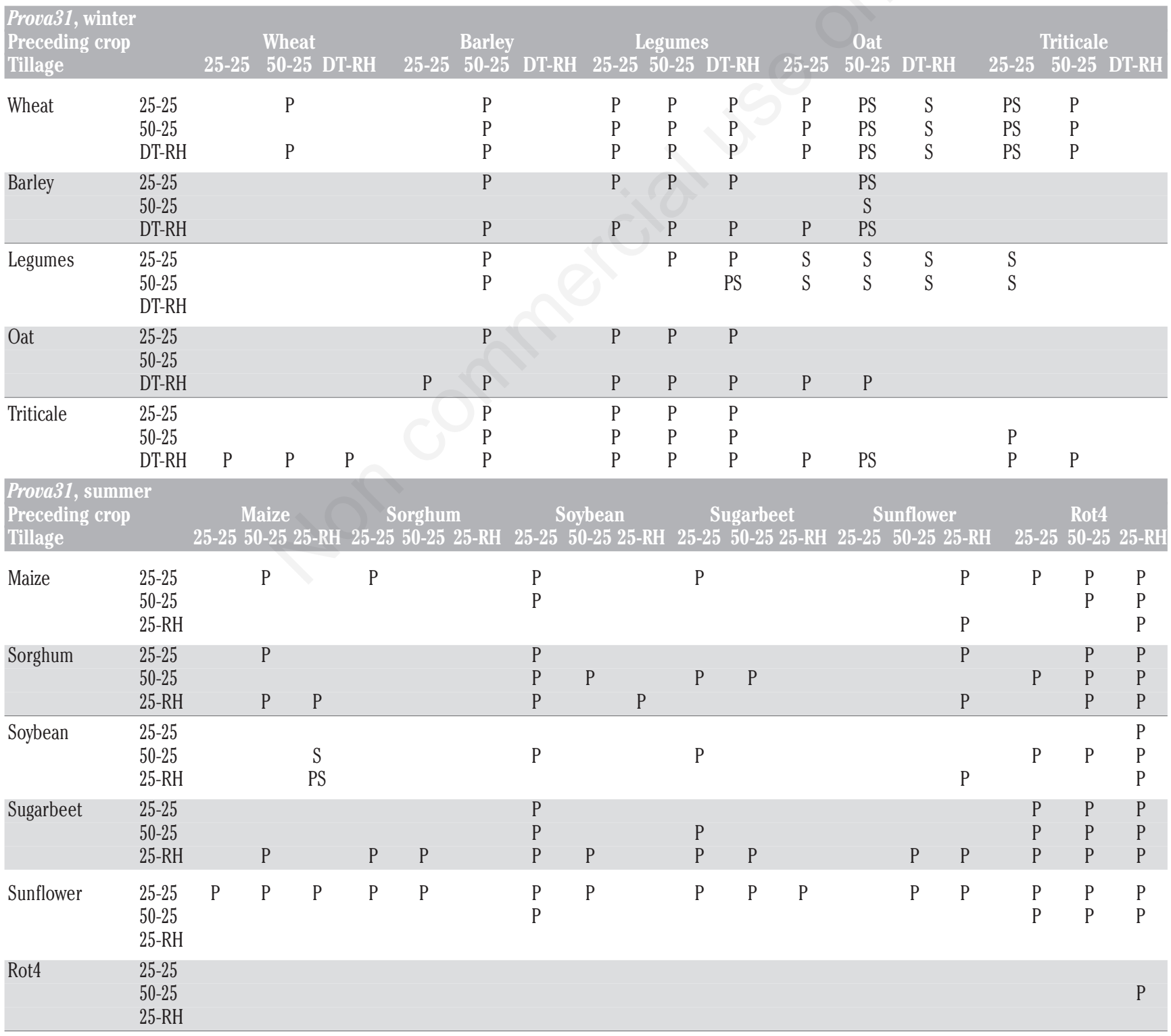

25-25, repeated tillage; 50-25, alternate deep tillage; DT-RH, non-mixing tillage; 25-RH, reduced tillage; Rot4, 4-year rotation; P, parametric dominance; S, stochastic dominance. 
Such condition is normally due to suboptimal plant health related to water and nutrient stress or to water-logging, making the crop more susceptible to pathogen attacks.

Also Prova29 showed a great benefit of organic amendments in wheat production, an effect that was less evident in maize.

In Prova31 the preference of winter preceding crop as legumes and oat is also well known, an impact hardly reachable with summer crops, with the exception of a rotation of a greater complexity, contributing in limiting weed and pathogen propagation.

\section{Conclusions}

The dominance method adds to classic ANOVA the direction of the effect of a treatment; it also constitutes a comparative approach that allows generating maps by comparing technical options and practices on the basis of treatments explored in LTAEs. The derived maps could collect most information resulting from those trials and useful for decisional purposes.

Parametric and stochastic dominance allows covering the majority of cases in agreement with prior results, displayed in tables so rich of information.

When referring to the treatments of Bologna LTAEs, dominance analysis also confirmed that conservative agriculture, here represented by longer rotation, amendments and reduced ploughing, can favour the economical sustainability of cropping.

If we look at the results in a climate change perspective, a preference map is also useful, because it gives the farmer a full set of available choices for the very last decision-making.

Stochastic dominance is definitely an interesting decision tool whose methodology can easily be enhanced when applied to the large number of LTAEs that are available in the world (Liebig et al., 2016).

\section{References}

Acock B, Acock MC, 1991. Potential for using long-term field research data to develop and validate crop simulators. Agron. J. 83:56.

Annicchiarico P, 2002. Genotype x environment interactions: challenges and opportunities for plant breeding and cultivar recommendations. FAO, Rome, Italy.

Borghi B, Giordani G, Corbellini M, Vaccino P, Guermandi M, Toderi G, 1995. Influence of crop rotation, manure and fertilizers on bread making quality of wheat (Triticum aestivum L.). Eur. J. Agron. 4:37-45.

Castaneda-Vera A, Garrido A, Minguez MI, 2015. Yield gap analysis and crop insurance. In: Proc. of the 5th International Symposium for Farming Systems Design, 7-10 September 2015, Montpellier, France, pp. 123-4.

Fishburn P, 1977. Mean-risk analysis with risk associated with below-target return. Am. Econ. Rev. 67:116-25.

Johnston AE, Powlson DS, 1994. The setting-up, conduct and applicability of long-term field experiments in agricultural research. In: E.D. Greenlab and I. Szabolcs (eds.). Soil resilience and sustained land use. CABI, Wallingford, UK. pp. 395-421.

Harwood J, Heifner RG, Coble K, Janet P, Somwaru A, 1999. Managing risk in farming: concepts, research and analysis. Economic Research Service, Washington, DC, USA.

Kamkar B, Akbari F, Jaime AS, Silva T da, Alireza MN, 2014. The effect of crop residues on soil nitrogen dynamics and wheat yield. Adv. Plants Agric. Res. 1:1-7.

Laanemets O, Viira A-H, Nurmet M, 2011. Price, yield, and revenue risk in wheat production in Estonia. Agron. Res. 9:421-6.

Liebig MA, Franzluebbers AJ, Alvarez C, Chiesa TD, Lewczuk N, Piñeiro G, Posse G, Yahdjian L, Grace P, Machado Rodrigues Cabral O, Martin-Neto L, de Aragão Ribeiro Rodrigues R, Amiro B, Angers D, Hao X, Oelbermann M, Tenuta M, Munkholm LJ, Regina K, Cellier P, Ehrhardt F, Richard G, Dechow R, Agus F, Widiarta N, Spink J, Berti A, Grignani C, Mazzoncini M, Orsini R, Roggero PP, Seddaiu G, Tei F, Ventrella D, Vitali G, Kishimoto-Mo A, Shirato Y, Sudo S, Shin J, Schipper L, Savé R, Leifeld J, Spadavecchia L, Yeluripati J, Del Grosso S, Rice C, Sawchik J, 2016. MAGGnet: an international network to foster mitigation of agricultural greenhouse gases. Carbon Manag. 7:243-8.

Levy H, 2015. Stochastic dominance: investment decision making under uncertainty. Springer, Berlin, Germany.

Mapp HP, Helmers GA, 1984. Methods of risk analysis for farm firms. In: P.J. Barry (ed.). Risk management in agriculture. Iowa State University Press, Ames, IA, USA. pp. 116-28.

Mavi HS, Tupper GT, 2004. Agrometeorology: principles and applications of climate studies in agriculture. CRC Press, Boca Raton, FL, USA.

Mugo SN, 1999. Drought tolerance at seedling and flowering growth stages in maize: abscisic acid and other traits as selection tools. PhD. thesis. Cornell University, Ithaca, NY, USA.

Nannipieri P, 1993. Ciclo della sostanza organica nel suolo. Patron, Quarto Inferiore (BO), Italy.

Payne RW, 2105. The design and analysis of long-term rotation experiments. Agron. J. 10:772-85.

Poulton PR, 1996. The Rothamsted long-term experiments: are they still relevant? Can. J. Plant Sci. 76:559-71.

Sivakumar VKM, Iotha RP, 2008. Managing weather and climate risks in agriculture. Springer, Berlin, Germany.

Toderi G, Stefanelli G, Marenghi A, Triberti L, 2000. Effetti di avvicendamento colturale e di tecnica di lavorazione del terreno ottenuti in ambiente pedecollinare con sistemi colturali semplificati. Nota I: Risultati produttivi ottenuti con specie autunno-primaverili. Rivista Di Agronomia 34:251-60.

Triberti L, Nastri A, Giordani G, Comellini F, Baldoni G, Toderi G, 2008. Can mineral and organic fertilisation help sequestrate carbon dioxide in cropland? Eur. J. Agron. 29:13-20.

Triberti L, Nastri A, Baldoni G, 2016. Long-term effects of crop rotation, manure and mineral fertilisation on carbon sequestration and soil fertility. Eur. J. Agron. 74:47-55.

Uzea N, Poon K, Sparling D, Weersink A, 2014. Farm support payments and risk balancing: implications for financial riskiness of Canadian farms. Can. J. Agr. Econ. 62:595-618.

Williams JR, Llewelyn RV, Barbany GA, 1990. Risk analysis of tillage alternatives with government programs. Am. J. Agr. Econ. 72:172-81. 